\title{
Corrigendum
}

\section{Association of vitamin D insufficiency with adiposity and metabolic disorders in Brazilian adolescents - Corrigendum}

Renata MS Oliveira, Juliana F Novaes, Lorena M Azeredo, Ana Paula C Cândido and Isabel CG Leite

First published online 28 May 2013

doi:10.1017/S1368980013001225, published online by Cambridge University Press 9 May 2013

On page 1, the name of the third author is incorrect.

Lorena M Azeredo

Should read:

Luiza M Azeredo

\section{Reference}

Oliveira RMS, Novaes JF, Azeredo LM, Cândido APC \& Leite ICG (2013) Association of vitamin D insufficiency with adiposity and metabolic disorders in Brazilian adolescents. Public Health Nutrition, published online 9 May 2013, doi:10.1017/S1368980013001225.

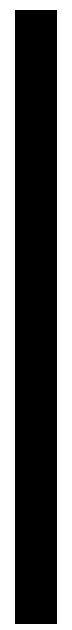

\section{Corrigendum}

\section{Barriers and facilitators of consumer use of nutrition labels at sit-down restaurant chains - Corrigendum}

Amy H Auchincloss, Candace Young, Andrea L Davis, Sara Wasson, Mariana Chilton and Vanesa Karamanian

First published online 3 May 2013

doi:10.1017/S1368980013000104, published online by Cambridge University Press 7 February 2013

The published title is incorrect. It should be:

Barriers and facilitators of consumer use of nutrition labels at full-service restaurant chains.

\section{Reference}

Auchincloss AH, Young C, Davis AL, Wasson S, Chilton M and Karamanian V (2013) Barriers and facilitators of consumer use of nutrition labels at sit-down restaurant chains. Public Health Nutrition, published online 7 February 2013, doi:10.1017/S1368980013000104. 